\title{
Evaluation of the Grammar Teaching Process by Using the Methods Used in Turkish Language Teaching as a Foreign Language: A Case Study
}

\author{
Başak Karakoç Öztürk \\ Department of Turkish Language Education, Faculty of Education, Çukurova University, Turkey
}

Copyright $(2018$ by authors, all rights reserved. Authors agree that this article remains permanently open access under the terms of the Creative Commons Attribution License 4.0 International License

\begin{abstract}
The preferred methods for the success of foreign language teaching and the reflection of these methods on the teaching process are very important. Since approaches and methods in language teaching enable the teacher to use different techniques in his/ her lectures, they provide a more effective teaching process. The methodology in teaching the Turkish language as a foreign language is generally discussed for the development of language skills, and there is not enough emphasis on which methods are used and how they are reflected in the linguistic teaching process. In teaching grammar, some aspects are adopted such as learning the rules and structures directly, following a specific order and transferring them, intimidating those rules by integrating with language skills and even ignoring teaching the grammar. The starting point of the study is to determine the reflection of these perspectives upon the teaching of grammar and to investigate which methods are used in the teaching of grammar. The purpose of the study is to determine the methods and techniques which the teacher uses by teaching grammar through teaching the Turkish language as a foreign language. In this way, the process of teaching grammar will be assessed by taking into account the beliefs and views of teachers. In this study, the case study among qualitative research patterns will be used. The lecturers who work in Turkish Language Teaching Centers in various universities and the volunteers to participate in the study will build up the study group. The data will be collected using the interview technique and the resulting data obtained will be analyzed through the content analysis. As a result of the study, suggestions will be brought up from the perspectives of teachers, from the methods they use and from the applications of what they do. Hence, it is hoped that awareness can be raised in the design of a grammar teaching process.
\end{abstract}

Keywords Turkish Language Teaching as a Foreign Language, Grammar Teaching, Method, Teaching Process

\section{Introduction}

There are many variables that affect the quality of teaching in the process of teaching a foreign language. Language teachers, learners' characteristics, learning environment, motivational qualities, cultural characteristics, methods, tools and materials are some of them. According to Demirel [1], the problem of foreign language teaching is basically a methodological problem. The way to achieve success at the highest level in teaching is primarily based on the methods to be followed in the teaching of a target language. Teaching methods involve the applications to be performed by teachers to achieve the desired learning and to reach the teaching objectives.

The methods preferred by language teachers for the success of teaching the Turkish language as a foreign language and the reflection of these methods on the teaching process are very important because methodology enables the teacher to use different techniques in his/her course, and thus it ensures a more effective teaching process. The methodology in teaching the Turkish language as a foreign language is generally discussed for the development of language skills, and sufficient emphasis is not placed on which methods are used and how they are reflected in the grammar teaching process.

However, it is possible to examine the presence and influence area of grammar teaching in foreign language teaching based on language teaching approaches and methods. It is observed that linguistic and learning theories in the historical process have influenced and shaped the area allocated to grammar in the instructional designs of language teaching approaches and methods [2].

The methods that have been used in foreign language teaching generally emerged for the purpose of meeting the deficiencies or insufficient points of an existing method, 
and these efforts have contributed to the better teaching of a foreign language and have brought alternative methods to this field. The language teaching methods that have been adopted and commonly used by the Council of Europe Modern Languages Department are as follows [3]:

1. Grammar-Translation Method

2. The Direct Method

3. Audio-Lingual Method

4. Cognitive-Code Method

5. The Natural Method

6. Communicative Method

7. Eclectic Method

The basic characteristics of these methods and how they are reflected on grammar teaching in the language teaching process are important starting points for the study.

\subsection{The Role of Language Teaching Methods in Grammar Teaching}

Grammar was the dominant teaching element in foreign language teaching until the beginning of the $20^{\text {th }}$ century [4]. Nevertheless, the importance and the time allocated to grammar in language teaching continue to exist as the subjects discussed in the literature. According to Tompkins [5], teachers, parents and the relevant academicians are not in a consensus about how grammar should be taught in the language teaching process. In the teaching of grammar, some approaches are adopted such as teaching the rules directly, making understand them by integrating with language skills and even ignoring teaching the grammar, the perspectives of the methods used on grammar teaching are different, and these changes are reflected in the teaching process.

Hinkel and Fotos have stated that foreign language teaching has meant performing analyses for grammar and translating the written works for more than 2000 years [6]. In the grammar-translation method that is known as one of the oldest language teaching methods, grammar has been considered as the set of rules required for linguistic production. Accordingly, grammar was presented in an explicit and deductive way, and performing teaching based on reinforcement through reading and translation activities after learning the grammar rules was adopted [4]. This method is based on the philosophy of teaching language rules and language structure intensively; making students memorize the vocabulary of the language with the help of vocabulary lists, and making students perform translation studies from a target language into their mother language and from their mother language into a target language. It has continued to be included in teaching processes until today without losing its effect despite many foreign language teaching methods following it [7]. According to Hinkel and Fotos [6], it was determined that students who learned a foreign language by the grammar-translation method could not use the language as a means of communication although they knew many grammar rules.
Therefore, this method began to be criticized.

Along with the direct method that emerged as a reaction to the grammar-translation method that regards grammar teaching as the objective of language teaching, and then the audio-lingual method, the acquisition of the verbal skill in the target language through the implicit and gradual teaching of grammar was aimed. In these methods in which structuralist language descriptions and behavioral learning principles are reflected in language teaching, language teaching was designed by the assumption that the continuous repetition and transformation of linguistic structures presented in an inductive way would result in a verbal habit and use [2].

When it came to the $1960 \mathrm{~s}$, the Behaviorism and Structural Linguistics and the methods based on them were criticized because they failed to explain the learning process and the structure of the language. Chomsky proposed the Transformational Generative Grammar Theory as a mental grammar model to explain the sentence generation. The Cognitive Language Learning Method indicating that language is an effective mental process rather than the process of gaining a habit was developed. It is believed that grammar is too complicated to learn by natural means, and students should go through a mental process to gain grammatical performance [6]. According to the cognitive approach that emerged as a reaction to the learning and teaching understanding of the behavioral approach, language learning takes place by learning rules, not by gaining habits, and it is a process that requires the conscious effort of a human. Unlike other methods, the cognitive method has attached importance to the fact that new information makes sense by integrating with old information in the teaching of language rules. Therefore, the idea that the teaching of grammar should be performed to enable students to create new meanings based on their previous information came to the forefront according to this method.

In the 1970s, a different perspective emerged in language teaching, and the argument that teaching a rule, therefore, knowing a rule does not mean that this rule could definitely be used during communication began to be adopted by some researchers. For this reason, it was concluded that grammar exercises were unnecessary and that the only thing required to teach another language was to ensure that students had natural communicative duties [6]. Krashen stated that grammar should not be taught, explicit grammar teaching should not be performed, and that language acquisition would occur while communicating in a natural way. Krashen's Natural Approach was influential in the emergence of the communicative method [6].

American and English linguists regarded the communicative method as an approach having the aim of improving communication skills that is the main purpose of language teaching and improving the listening, speaking, reading and writing skills that are the four areas of 
language that link the language and communication to each other [8]. The focus on language use brought the communicative aspect of language to the forefront, and the structure-oriented exercises were replaced by the applications based on courses and the communicative method that are focused on functions in which the structure and morphology are not explained too much and students are directly oriented to communicative activities. However, the facts that it was intensively focused on communication and being fluent in the language was brought to the forefront by the communicative method, and that this was considered more important than making correct sentences from grammatical aspects ignored the 'fossilization' of mislearned structures in the student; moreover, it became difficult for students to cope with the complicated structures faced by them in the language they learned [9].

According to different perspectives proposed by the methods in language teaching, it was argued that none of the methods was strong enough to solve all teaching problems alone and that teachers, as well as theorists, would deliver solutions to the problems experienced due to the fact that each method criticized the previous one and emerged as an alternative to it [10]. The teacher should use the convenient aspects of each method according to the current situation in the class and the needs of students. In this context, the idea of using a method appropriate to each learning situation instead of relying on a single method in the language teaching process led to the emergence of a mix of methods that was called eclectic [11].

On the basis of this theoretical background, it was assumed that how different perspectives and different methods used in Turkish language teaching as a foreign language are reflected on grammar teaching process, and which methods are used in this process would be important, and this thought constituted the starting point of the study. As a result of the study, it is hoped that providing data and suggestions based upon the perspectives of teachers, who are the planners of Turkish language teaching as a foreign language, on language teaching and grammar, the methods they use, and the applications of what they do can create awareness in designing an effective grammar teaching process.

Teachers' thoughts and applications regarding the teaching of grammar were studied to determine the place of grammar in foreign language courses abroad. Whether focusing on form in grammar teaching was more effective in advanced students compared to those at the beginner level was investigated. In addition to this, focusing on form at the request of students was also studied [6].

In some studies in which the problems encountered in Turkish language teaching as foreign language in Turkey were discussed, it was determined that there were problems related to the field of grammar. For example, [12] determined in their study that the fields in which students learning the Turkish language as a foreign language mostly had problems were grammar and speaking. Except this, [13, $14,15]$ revealed in their studies that there were problems related to the teaching of grammar. However, when the relevant literature was reviewed, it was observed that there were a limited number of studies on the methods of Turkish language teaching as a foreign language $[3,11,16,17]$. From this point of view, the purpose of the study was to determine the perspectives of language teachers on language teaching and grammar and the methods they use in Turkish language teaching as a foreign language, and their awareness of these methods, and thus to evaluate the grammar teaching process by taking into account the opinions of teachers.

\subsection{Purpose}

The purpose of the study is to determine the perspectives of language teachers on language teaching and grammar and the methods they use in Turkish language teaching as a foreign language, and their awareness of these methods, and thus to evaluate the grammar teaching process by taking into account the opinions of teachers.

\section{Method}

\subsection{Research Design}

This study was designed as a case study among qualitative research methods. In case studies, how individuals related to a situation are affected by this situation and their perspectives on this situation are investigated. The factors related to a situation (individual, events, processes, environment) are investigated, and how they affect the relevant situation or how they are affected by the relevant situation are focused on [18]. In the study carried out, grammar teaching was selected as the case, the lecturers teaching Turkish as a foreign language were determined as one of the factors related to this case, and their opinions were used.

\subsection{Study Group}

The study group of the research was determined by the convenience sampling method, one of purposeful sampling methods. Agreeing to have an interview and volunteering to participate in the study were also taken into account. In this context, the lecturers working in Turkish Language Teaching Centers in various universities constituted the study group. Personal information about the study group is presented in Table 1. 
Table 1. Personal Information about the Study Group

\begin{tabular}{|c|c|c|}
\hline & & $\mathbf{N}$ \\
\hline \multirow{2}{*}{ Gender } & Female & 26 \\
\hline & Male & 16 \\
\hline \multirow{3}{*}{$\begin{array}{c}\text { Educational } \\
\text { Status }\end{array}$} & Master's Degree & 28 \\
\hline & Doctorate & 12 \\
\hline & Undergraduate & 2 \\
\hline \multirow{3}{*}{$\begin{array}{l}\text { Faculty of } \\
\text { Graduation }\end{array}$} & Faculty of Education & 19 \\
\hline & Faculty of Science and Literature & 18 \\
\hline & Other & 5 \\
\hline \multirow{4}{*}{$\begin{array}{l}\text { Department of } \\
\text { Graduation }\end{array}$} & Turkish language and literature & 18 \\
\hline & Turkish Language Education & 10 \\
\hline & Other & 8 \\
\hline & Turkish Language and Literature Education & 6 \\
\hline \multirow{5}{*}{$\begin{array}{l}\text { Professional } \\
\text { Seniority }\end{array}$} & $0-5$ Years & 13 \\
\hline & $6-10$ Years & 10 \\
\hline & $11-15$ Years & 7 \\
\hline & More than 20 years & 8 \\
\hline & $16-20$ Years & 4 \\
\hline \multirow{6}{*}{$\begin{array}{c}\text { The Institution } \\
\text { Where They } \\
\text { Work }\end{array}$} & Çukurova University & 10 \\
\hline & Mersin University & 10 \\
\hline & Gazi University & 9 \\
\hline & Adana Science and Technology University & 6 \\
\hline & Nevşehir Hacı Bektaş Veli University & 5 \\
\hline & Hacettepe University & 2 \\
\hline \multirow{4}{*}{$\begin{array}{c}\text { Turkish } \\
\text { Teaching Sets } \\
\text { Used }\end{array}$} & Yunus Emre Institute Turkish Teaching Set & 21 \\
\hline & $\begin{array}{c}\text { Istanbul Turkish Teaching Set for } \\
\text { Foreigners }\end{array}$ & 10 \\
\hline & $\begin{array}{c}\text { Gazi Tömer Turkish Teaching Set for } \\
\text { Foreigners }\end{array}$ & 9 \\
\hline & Hitit & 2 \\
\hline
\end{tabular}

As it is seen in Table 1, 26 of the interviewed lecturers were female, and 16 of them were male. 28 of the lecturers had a master's degree, 12 of them had a doctorate degree, and 2 of them had an undergraduate degree, and 19 of them graduated from the faculty of education, 18 of them graduated from the faculty of science and literature, and 5 of them graduated from another faculty. It was determined that four of these 5 people graduated from the Faculty of Language, History and Geography, and one of them graduated from the faculty of economics administrative and social sciences. It was also determined that 18 of the lecturers graduated from the Department of Turkish language and literature, 10 of them graduated from the Turkish Education Department, 6 of them graduated from the Department of Turkish Language and Literature Education; and regarding the lecturers who marked the other category, 3 of them graduated from the department of linguistics, 3 of them graduated from the English Language Teaching, one of them graduated from the German language and literature and one of them graduated from the Department of Contemporary Turkish Dialects and Literature. When they are examined in terms of their professional seniority, it is observed that more than half of the lecturers have a seniority between 0 and 10 years. 10 of the interviewed lecturers work at Çukurova University, 10 of them work at Mersin University, 9 of them work at Gazi University, 6 of them work at Adana Science and Technology University, 5 of them work at Nevşehir Hacı Bektaş Veli University, and 2 of them work at Hacettepe University.

\subsection{Data Collection}

Within the scope of the study, the interview technique was used to determine the opinions and thoughts of the lecturers about language teaching and grammar teaching as a field in language teaching, and the methods they use. For this purpose, a semi-structured interview form developed by the researcher was used. In the process of preparing the form, a draft interview form was firstly prepared on the basis of language teaching methods. The pilot study of the interview form, which was formed by receiving the opinions of three domain experts, was conducted by interviewing 5 lecturers. Arrangements were made in some questions based on the appearance revealed by the pilot study, and the form was put into final form. Closed-ended and open-ended question types were included in the interview form.

For example, in addition to open-ended questions such as "What do you think is the purpose of grammar teaching in the process of Turkish language teaching as a foreign language?", the lecturers were asked to indicate the degree of agreeing with some approaches mentioned with regard to grammar teaching according to 7-point rating. The lecturers were asked to explain in writing the reasons for the answers they gave to the closed-ended questions in the interview form.

For example, "Is grammar teaching important in the process of Turkish language teaching as a foreign language? Why?

Because 


\subsection{Data Analysis}

The data obtained within the scope of the study were analyzed by the content analysis method. The content analysis requires in-depth analysis of the data collected and allows various themes and codes to be revealed [18]. The data including the answers given by the lecturers to open-ended questions were read several times, and the notes related to possible codes were taken. The literature related to the concepts used and the interview questions were taken into account while generating the codes. Some statements used by the lecturers and the concepts determined by the researcher were also used as the codes. After coding was performed, the themes that would collect the codes were determined. These main themes were also determined in line with the interview questions.

The data obtained were also examined by a Turkish language education domain expert and a lecturer teaching the Turkish language as a foreign language apart from the researcher to increase reliability, and agreement was ensured for the designated codes. While the interview data were reported, direct quotations were provided to reflect the perspectives of the lecturers, the word lecturer was abbreviated by the letter "L", and these letters were added to the end of the quotations with the numbers assigned to the lecturers (e.g. L3).

\section{Findings and Discussion}

Firstly, the lecturers in the study group were asked about the purpose of language teaching to learn their perspectives on language teaching, and the obtained results are presented in Table 2.

Table 2. The Results Regarding the Purpose of Language Teaching

\begin{tabular}{|c|c|c|}
\hline & & f \\
\hline • & To ensure establishing communication & 28 \\
\hline • & Culture transfer & 11 \\
\hline$\bullet$ & To provide job opportunity & 3 \\
\hline$\bullet$ & To meet student's needs & 2 \\
\hline • & To show the beauties of the target language & 1 \\
\hline$\bullet$ & To adapt to social life & 1 \\
\hline$\bullet$ & To establish economic and political connections & 1 \\
\hline
\end{tabular}

The question of "What do you think is the purpose of language teaching?" was asked to the interviewed lecturers, and more than half of the lecturers stated that the purpose was to improve the ability to communicate in the target language. On the other hand, 11 lecturers talked about the purpose of ensuring culture transfer while 3 lecturers talked about providing job opportunity, 2 lecturers talked about meeting student's needs, a lecturer talked about showing the beauties of the target language, a lecturer talked about adapting to the society in which the target language is spoken, and a lecturer talked about establishing economic and political connections through language teaching. Two lecturers expressed their opinions on this subject as follows:

"The purpose of language teaching is to improve communicating in the target language. It also has a purpose of showing the beauties of the target language."(L4)

"I think the purpose of language teaching is to teach the culture to which the language belongs." (L14)

Language is most basically considered as a tool that enables communication among people, and the fact that the common point in many definitions is communication attracts the attention while defining the language. Communicating in that language, and ensuring written and verbal communication, which is the main function of language, [19] are in the basis of language learning. While lecturing constitutes an aspect of communication through language, comprehension constitutes the other aspect of it [20]. In this context, it was determined that some lecturers emphasized the development of language skills for communicating while stating the purpose of language teaching. For example, a lecturer expressed his opinions on this subject by stating that "It is to make students be able to communicate by speaking and writing the language and by comprehending what they read and listen" (L23).

In addition to this, foreign language learning also means understanding a world and a foreign culture [21]. Each culture finds its expression in a different language, and the language establishes and develops the culture. Foreign language learners should learn the cultural data required for communication, and thus, improve their communication skills [22]. Therefore, the teaching of a foreign language requires that students should be taught to establish a relationship with the culture of that language, in other words, teaching the culture of that language. Within the scope of the study, it can be said that the fact that most of the language teachers attributed the purpose of language teaching to basic functions such as communicating and introducing the culture of the target language is the result that is consistent with the literature.

The lecturers in the study group were asked to write three of the methods that they used and considered as effective in language teaching, and the obtained results are presented in Table 3.

One of the results obtained as a result of the interviews is related to which methods the lecturers use in Turkish language teaching as a foreign language. For this purpose, the lecturers were asked to write three of the methods that they used and considered as effective in language teaching. As it is seen in Table 3, it was determined that the method that most of the lecturers considered effective was the communicative method. When the results were examined, it was observed that 20 out of 30 lecturers wrote the communicative method in the first place. The other method that most of the lecturers considered effective apart from the communicative method was the eclectic method. It was 
determined that they were followed by the audio-lingual, cognitive, grammar-translation and natural methods.

Table 3. The Results Regarding the Methods that Are Used and Considered as Effective in Language Teaching

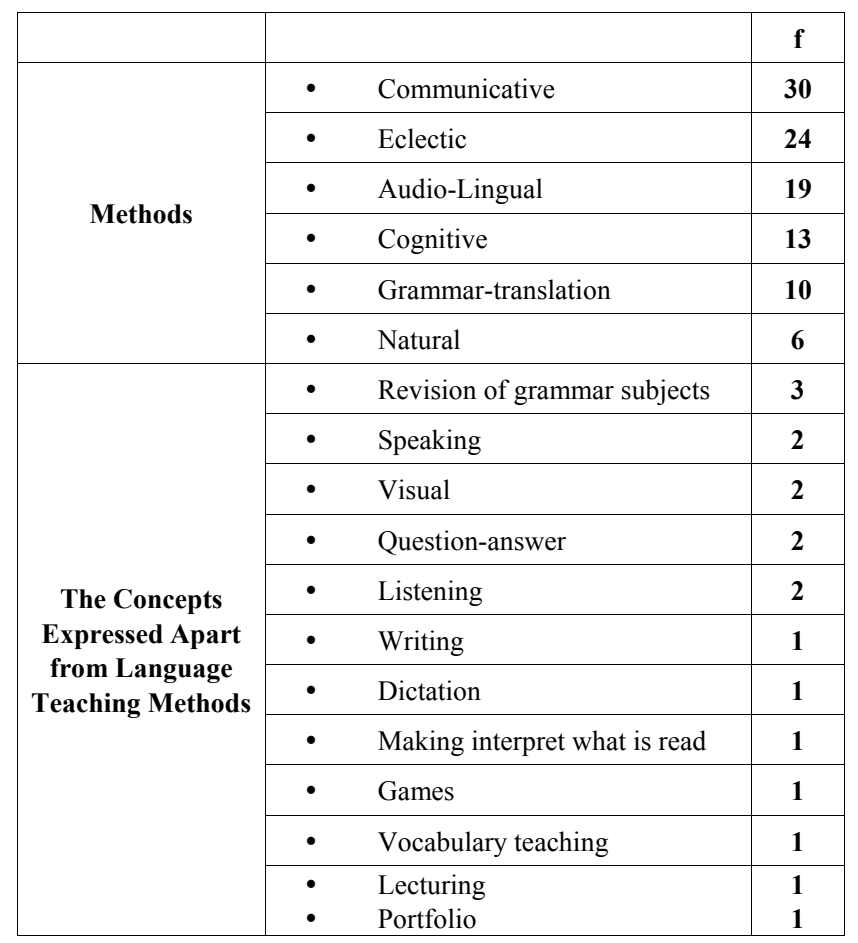

The communicative method accepts the language as a means of communication and argues that the main purpose of language teaching is to make students gain the communicative competence compatible with their needs in the target language $[3,11]$. Since it has been observed that learners are unsuccessful in terms of using the language in the cultural environments of the language learned, performing applications in which real-life situations are centered through the communicative method has come to the forefront, and it is aimed to teach the language used in these situations [23]. Along with the introduction of the concept of communicative competence [19], which emphasizes that it will not be sufficient to generate only correct sentences from a grammatical aspect in the language, and also these sentences should be used in appropriate contexts, grammar teaching in language teaching was drifted away, and it was focused on the development of language use, it was aimed to generate sentences appropriate for the function and to communicate fluently in the language [9].

Within the scope of the study, the reason for the fact that most of the lecturers considered the communicative method effective may be the facts that students believe in the benefits of the communicative method mentioned in the literature such as the fact that it requires that students should pay attention to their own experiences, it creates a student-centered teaching environment, and the motivation of students for language learning will increase when their communication skills begin to develop [24], and that the communicative method is based on an approach that has come to the forefront and has been commonly used in today's language teaching.

It is remarkable that the cognitive method based on the cognitive approach that emerged as a reaction to the behavioral approach, along with the methods such as the audio-lingual and grammar-translation methods based on the behavioral approach as well as the communicative method, is considered as an effective method in language teaching by some lecturers, and this result can be interpreted as the fact that the interviewed lecturers have different perspectives on language teaching. However, the fact that the eclectic method was considered effective by more than half of the lecturers is important in terms of showing that an approach based on using the useful and appropriate aspects of different methods based on different approaches was adopted. The fact that a method is always used according to individual differences, the level of learning and classroom size may not yield successful outcomes in terms of learning. Therefore, it can be said that understanding that it is not right to separate language teaching methods from each other with precise lines and to be dependent on a single method [17] is influential on language teachers' perspectives on language teaching.

Within the scope of the research results, it was determined that speaking, writing, listening and reading skills were accepted and written as a method. These are the four basic language skills and are the skills intended to be developed through the methods used in language teaching. Therefore, they cannot be accepted as a language teaching method. In addition to these, it was determined that general teaching methods such as lecturing, question-answer and revision were also written as a language teaching method and that teaching materials such as visuals and games were accepted as a method and expressed as an effective language teaching method. These results are important in terms of showing that there is a problem related to awareness based on methodology and methods in language teaching. In some studies carried out [14, 25], it has been mentioned that there is a methodological problem in the field of Turkish language teaching as a foreign language, supporting this result.

Within the scope of the study, whether the teaching of grammar was important and the reasons for it were asked to the lecturers, and the obtained results are presented in Table 4.

Whether the teaching of grammar was important was asked to the lecturers interviewed within the scope of the study, and as it is seen in Table 4, the vast majority of the lecturers stated that the teaching of grammar was important. This research result, although the study groups were different, is compatible with the result of the study carried out by [2]. In the study in question, almost $90 \%$ of 200 students studying in the department of linguistics stated that the teaching of grammar is important in the foreign language learning process. Within the scope of the study, 
only one lecturer stated that grammar teaching was not important because it moved away from communicating, and a lecturer stated that it was not important because he considered it useless.

Table 4. The Results Regarding the Importance of Grammar Teaching

\begin{tabular}{|c|c|c|c|}
\hline & & & f \\
\hline \multirow{6}{*}{ Yes (40) } & • & Helps to improve language skills & 20 \\
\hline & $\bullet$ & Facilitates the use of the target language & 12 \\
\hline & & $\begin{array}{l}\text { Ensures comprehending the logic of the } \\
\text { target language }\end{array}$ & 8 \\
\hline & • & Improves speaking and writing skills & 6 \\
\hline & $\bullet$ & Eliminates writing problems & 1 \\
\hline & • & Increases the academic achievement & 1 \\
\hline No (1) & $\bullet$ & Moves away from communication & 1 \\
\hline Undecided (1) & $\bullet$ & It is useless & 1 \\
\hline
\end{tabular}

As it is seen in Table 4, while 20 of the lecturers thinking that grammar teaching was important stated that grammar teaching helped to improve language skills, 12 of them stated that it facilitated the use of the target language, and 8 of them stated that it ensured comprehending the logic of the target language. While one of the lecturers, who expressed their opinions on this subject, stated that "Grammar is helpful to improve language skills in a holistic manner and to comprehend the target language."L15, another lecturer, who opposed this view, expressed his opinions by stating that "Grammar teaching moves away students from communicating. Language learners cannot learn the language through grammar.'L40.

According to [26], the approach in the European Language Portfolio is to ensure that language learners learn the language in line with their communication purposes. In line with this prediction, learning grammar rules was accepted as a tool to achieve communicative purposes. According to [27], grammar is important when it is considered that the Turkish language is one of the agglutinative languages, and paying attention to it will facilitate the teaching of the Turkish language. However, learning the rules of a language does not mean learning that language. A language is considered to have been learned by being able to understand that language through reading and listening and being able to express in that language through speaking and writing. For this reason, grammar rules should be taught as helpful information in understanding and expressing activities [28]. According to [29], grammar teaches the art of using the language well. It helps us to understand and express the thoughts and feelings more properly and completely. We also get used to thinking more accurately and more perfectly through grammar. This knowledge is the protector of linguistic order.

The fact that most of the lecturers within the scope of the study expressed opinions in this direction can be interpreted as the fact that they pay attention to grammar teaching and accept language rules as a tool that will facilitate the use of the target language and will ensure understanding the logic of it in the process of developing the learner's speaking, writing, listening and reading skills.

As it is seen in Table 4, some lecturers also considered grammar important since it helps to improve speaking and writing skills. The speaking skill that constitutes the other leg of expression along with the writing skill is the skill that foreign language learners mostly need in daily life [30]. These skills are also the skills that should be actively used in the process of communicating and are generally problematic while learning a language. Speaking is the most problematic skill acquisition process in language learning [31]. Furthermore, it has been determined by some studies that the speaking skill is the most important skill in which those who learn the Turkish language as a foreign language mostly have difficulty $[32,33,34]$. Some of the lecturers whose opinions were received within the scope of this study thought that grammar teaching would facilitate the development of verbal and written expression skills of the language by contributing to the proper and effective use of the language, and they may have attributed importance to the teaching of grammar in this respect.

One of the questions asked to the lecturers was what the purpose of grammar teaching was. The results obtained in this context are presented in Table 5.

Table 5. The Results Regarding the Purpose of Grammar Teaching

\begin{tabular}{|cl|c|}
\hline & & $\mathbf{f}$ \\
\hline$\bullet$ & To contribute to establishing communication & $\mathbf{2 0}$ \\
\hline$\bullet$ & To teach the grammar rules & $\mathbf{1 8}$ \\
\hline$\bullet$ & To ensure the correct use of the language & $\mathbf{6}$ \\
\hline • & To improve speaking and writing skills & $\mathbf{6}$ \\
\hline - & To improve the speaking skill & $\mathbf{1}$ \\
\hline - & To correct pronunciation errors & $\mathbf{1}$ \\
\hline$\bullet$ & To ensure reading comprehension & $\mathbf{1}$ \\
\hline
\end{tabular}

The lecturers whose opinions were received within the scope of the study were asked about what the purpose of grammar teaching was; as it is seen in Table 5, 20 lecturers stated contribution to establishing communication while 18 lecturers stated teaching grammar rules. Apart from these, there were also lecturers who mentioned the purposes such as ensuring the correct use of the language, improving speaking and writing skills, correcting pronunciation errors, and ensuring reading comprehension. Three of the lecturers expressing their opinions on this subject stated that:

"It is to help to gain the ability to communicate in the target language. "L24

"Grammar teaching should be performed to support communication by improving language skills. ”L31

"The purpose is to teach the rules of the language, therefore, grammar teaching should be performed. Students should have a command of the language rules." L13

What the target group trying to learn the language in a 
place where they are strangers to the language mostly need is to use the language skills to communicate properly and to maintain the daily life without any problem. For this reason, in the study, the purpose of grammar teaching may be considered by some lecturers not only as teaching the rules of the target language but also as an area that contributes to communication. However, when the lecturers were asked about what the purpose of language teaching was during the interview, it was determined that more lecturers emphasized the improvement of communication skills. When they were asked about the purpose of grammar teaching, it was observed that the number of lecturers who stated the purpose of improving communication skills was smaller.

It was determined that the lecturers who emphasized the importance of teaching grammar rules while indicating the purpose of grammar teaching also came to the forefront and that these lecturers stated that the most important purpose of grammar teaching was to teach the grammar rules. Some studies have revealed that students cannot reach the expected linguistic competence when there is no focus on the rules in grammar teaching. With respect to students, grammar rules provide them with a basis on which they can hold in a new language complexity and enable them to generalize [6]. The lecturers may also have indicated that the most important purpose of grammar teaching was to teach the rules by thinking in the context of these opinions and believing in its necessity.

However, it is emphasized in the relevant literature that grammatical structures should be used within appropriate contexts to make a sense in communication although they consist of forms and rules. Accordingly, it is stated that the purpose of grammar teaching in a foreign language is to transfer grammar rules into the real life, in other words, to ensure that these rules are used while communicating to convey a meaning in that language [9].

Grammar is a dynamic process in which people use language-oriented structures to create meaning in accordance with the context [35]. If grammar is accepted not only as accumulation at the knowledge level but also as the use of grammatical structures in a correct, meaningful and appropriate manner, the teaching of grammar can also be considered not only as a transfer of knowledge but also as the development of the skill. To consider grammar as a skill, not just as a field of knowledge, may help to solve the ongoing problems of students.

Within the scope of the study, various statements reflecting the perspectives of language teaching methods on grammar teaching were presented, the lecturers were asked to read these statements and to mark the degrees of agreeing with these statements, the results reflecting the degrees of agreeing are presented in Table 6.

Table 6. The Results Regarding the Lecturers' Degrees of Agreeing with the Statements Reflecting the Perspectives of Language Teaching Methods on Grammar Teaching

\begin{tabular}{|c|c|c|c|c|c|c|c|c|}
\hline \multirow{3}{*}{ ITEMS } & \multirow{3}{*}{$\bar{x}$} & \multicolumn{7}{|c|}{ Degree of Agreeing } \\
\hline & & 1 & 2 & 3 & 4 & 5 & 6 & 7 \\
\hline & & $\mathbf{f}$ & f & $\mathbf{f}$ & f & $\mathbf{f}$ & $\mathbf{f}$ & $\mathbf{f}$ \\
\hline $\begin{array}{l}\text { 1. Grammar rules should be taught directly, should be memorized when necessary, and } \\
\text { should be reinforced by reading and translation activities. }\end{array}$ & 3.07 & 15 & 7 & 3 & 4 & 6 & 4 & 3 \\
\hline $\begin{array}{l}\text { 2. It is important to teach the rules of the language in grammar teaching and to be able to } \\
\text { do a translation between the mother language and the target language by using these } \\
\text { rules. }\end{array}$ & 3.47 & 7 & 12 & 3 & 4 & 9 & 4 & 3 \\
\hline $\begin{array}{l}\text { 3. It is important to make use of various structures through memorization of dialogues in } \\
\text { grammar teaching since it will ensure the formation of a habit for language use and will } \\
\text { reduce the errors. }\end{array}$ & 3.52 & 7 & 9 & 6 & 6 & 5 & 7 & 2 \\
\hline $\begin{array}{l}\text { 4. It is an effective way to teach a grammatical structure through repetition exercises in the } \\
\text { form of "hear-repeat" in grammar teaching. }\end{array}$ & 4.54 & 3 & 6 & 4 & 5 & 6 & 12 & 6 \\
\hline $\begin{array}{l}\text { 5. Induction and deduction should be used in the teaching of grammar rules, and the rules } \\
\text { should be taught by comparison and explanation made in the mother language. }\end{array}$ & 4.23 & 7 & 6 & 5 & 2 & 5 & 8 & 9 \\
\hline $\begin{array}{l}\text { 6. In grammar teaching, a newly-taught rule should be associated with previously-learned } \\
\text { rules. }\end{array}$ & 4.54 & 3 & 6 & 4 & 5 & 6 & 12 & 6 \\
\hline $\begin{array}{l}\text { 7. In grammar teaching, the most useful aspects of each method should be selected and } \\
\text { used. }\end{array}$ & 4.64 & 3 & 2 & 8 & 5 & 4 & 16 & 4 \\
\hline $\begin{array}{l}\text { 8. The language teacher should focus on bringing proficiency for the use of language } \\
\text { skills instead of transferring the grammar rules in the target language. }\end{array}$ & 4.92 & 4 & 2 & 4 & 2 & 10 & 11 & 9 \\
\hline $\begin{array}{l}\text { 9. A natural process in which the mother language is learned should be followed in the } \\
\text { teaching of the target language. }\end{array}$ & 4.21 & 2 & 4 & 10 & 8 & 6 & 9 & 3 \\
\hline $\begin{array}{l}\text { 10. Instead of analyzing the grammar rules, only the development of the verbal lecturing } \\
\text { skill and pronunciation should be emphasized. }\end{array}$ & 3.52 & 7 & 9 & 6 & 6 & 5 & 7 & 2 \\
\hline $\begin{array}{l}\text { 11. Independent studies should not be performed to teach grammar rules, language skills } \\
\text { should be improved through activities. }\end{array}$ & 4.64 & 3 & 2 & 8 & 5 & 4 & 16 & 4 \\
\hline
\end{tabular}


When Table 6 is examined, it is observed that the number of lecturers who marked numbers 5, 6 and 7 as the degree of agreeing with the item "The language teacher should focus on bringing proficiency for the use of language skills instead of transferring the grammar rules in the target language", that refers to the communicative method, is quite high. Similarly, the degree of agreeing with the item "Independent studies should not be performed to teach grammar rules, language skills should be improved through activities", that is a statement for the communicative method, of more than half of the lecturers is high. However, it is observed that there are also lecturers who never agree with these items that reflect the characteristic of the communicative method and who have a very low degree of agreeing with them. Furthermore, it is remarkable that more than half of the lecturers do not agree with the items "Grammar rules should be taught directly, should be memorized when necessary, should be reinforced by reading and translation activities", that refers to the grammar-translation method, and "It is important to teach the rules of the language in grammar teaching and to be able to do a translation between the mother language and the target language by using these rules" while there are also lecturers who highly agree with them by marking numbers 5, 6 and 7. The number of lecturers, who stated their degrees of agreeing with the item "It is an effective way to teach a grammatical structure through repetition exercises in the form of "hear-repeat" in grammar teaching", that is one of the statements that reflect the audio-lingual method, and the item "In grammar teaching, a newly-taught rule should be associated with previously-learned rules", that refers to the cognitive method, by marking numbers 5, 6 and 7, is higher than half of the study group.

Based on these results, it can be said that there is a group of lecturers with two different opinions when the opinions and thoughts of the lecturers in the study group on grammar teaching are taken into account. One of these opinions is that "the teaching of grammar should be performed by transferring the rules", and the items that refer to the grammar-translation method, the audio-lingual method that are based on the behavioral approach and the cognitive method that is based on the cognitive approach support this opinion. The items that refer to the natural and communicative methods argue that "explicit grammar teaching should not be performed". Nevertheless, it is observed that the majority of the lecturers indicated their degrees of agreeing with the item "In grammar teaching, the most useful aspects of each method should be selected and used" that refers to the eclectic method, by marking numbers 4, 5, 6 and 7. This result also gives a clue regarding the fact that an approach based on using the useful aspects of different methods based on different approaches has been adopted in grammar teaching.

Within the scope of the study, the lecturers were asked about what the methods they used in grammar teaching were, and the obtained results are presented in Table 7.

Table 7. The Results Regarding the Methods Used in Grammar Teaching

\begin{tabular}{|c|c|c|}
\hline & & f \\
\hline - & Communicative & 30 \\
\hline - & Eclectic & 25 \\
\hline - & Audio-Lingual & 24 \\
\hline - & Cognitive & 18 \\
\hline - & Grammar-Translation & 16 \\
\hline - & Natural & 11 \\
\hline
\end{tabular}

As it is seen in Table 7, most of the lecturers expressed that they used the communicative method in grammar teaching. This is followed by the eclectic, audio-lingual, cognitive, grammar-translation and natural methods. When these results were compared with the methods used by lecturers in language teaching, they showed that the lecturers used the methods based on teaching rules such as grammar-translation, audio-lingual and cognitive methods more in grammar teaching. It was also determined that there were lecturers who agreed with the item "Grammar rules should be taught directly...", the item "In grammar teaching, a newly-taught rule should be associated with previously-learned rules..." and the item "To make use of various structures through memorization of dialogues in grammar teaching..." in Table 6, supporting this result. In other words, some lecturers oppose the perspective of the communicative method in grammar teaching and think that grammar rules should be taught directly. It has been determined that this result is compatible with the results of some studies carried out abroad. For example, the results of the case study carried out by Yoon, Hoshi and Zhao suggest that students consider grammar teaching necessary for academic purposes. Colombian students learning the English language as a foreign language, it was determined those students had a positive attitude to learning grammar and preferred explicit grammar teaching. In addition to this, in various studies on the opinions of teachers and students about grammar teaching [2], in the relevant literature, imitation, memorization and pattern practices are stated to be useful for a person who has just started to learn a language, supporting these results. A person who has just started to learn a language cannot suddenly comprehend all the rules of the language he has learned in a meaningful way. These rules and some sentence patterns can be memorized at first, and then made meaningful [36].

It was determined that the communicative method that opposes to it was the most preferred method by most of the lecturers participating in the study. However, this method is also criticized in terms of some of its characteristics. The facts that the meaning has been replaced by the form and that fluency has gotten ahead of accuracy are considered as important reasons for this because one of the principles of the communicative method indicates that fluency should be kept in the forefront more than accurate use to support 
student's efforts to use the language in some cases [37]. Perfection is not required for grammar and pronunciation, and understandable pronunciation is considered important. Grammar rules are not taught since communicative competence is the target [17].

The questions about how and how much grammar will be taught in foreign language teaching should be answered [38]. When it is focused on the transfer of rules based on form, too many controlled exercises are performed, generative activities are less often included, and it is attempted to do with sample sentences that are out of context. Only the rules of grammatical structures are given, and the logic of these rules is not explained. When the usage and meaning dimensions are focused on, the dimension of form is never addressed; only the use of language for communication purposes is expected. However, it is necessary to meet on a common ground by moving away from these two extreme approaches to make students reach the level of competence based on intended grammar in language learning because each part of the language contains all three dimensions of form, meaning and use [6].

Fotos proposed that the best foreign language teaching would take place by adding communication activities to vocabulary, grammar and translation exercises. Some researchers such as Celce-Murcia, Dörnyei and Thurrell and Ellis also stated that both grammatical explanations and communication activities were required for the comprehension of the target structure and the implementation of these structures [6].

\section{Conclusions and Suggestions}

It can be said that language teaching is not just composed of grammar teaching and that it is not sufficient to know grammar rules to be able to combine words in the target language. The main point is that the student can use grammar rules in the target language effectively and accurately in a meaningful way and in accordance with the context. Therefore, instead of a teaching process in which grammar is ignored in the language teaching process, it is necessary to design teaching processes in which it is important to create awareness based on language rules, enabling learners to use language skills more effectively and to make meaningful and contextually compatible productions. In this context, the following suggestions can be made based on the results obtained within the scope of the study:

- The instructors who will teach the Turkish language as a foreign language should be made gain awareness of language teaching methods, and the theoretical information for the methods should be taught by being integrated with sample course applications.

- $\quad$ Language teaching methods should be taken as a basis while preparing the materials used in the process of Turkish language teaching as a foreign language. While language teachers are applying the useful principles of language teaching methods, they should also be informed about reaching the materials that will help them put into practice these principles and even developing materials.

- $\quad$ To be able to teach a language effectively and to develop the program according to this teaching, the structural and semantic characteristics of that language should firstly be defined in a structure from simple to complex in every aspect and in accordance with the level of learners. As it is known, there are works and valuable studies that describe the grammar of the Turkish language, but these works can mainly be a source for teaching the Turkish language as a foreign language [13]. For this reason, guidebooks should be prepared on how to perform Turkish grammar teaching as a foreign language more effectively.

- Different scientific studies should be carried out on the selection of methods and the new methods to be developed in the Turkish language teaching as a foreign language. It may be suggested to diversify the data and methods in the studies to be carried out on how grammar teaching is conducted in the Turkish language teaching as a foreign language by further including the qualitative studies in them, and to use qualitative research designs that particularly include the problems arising in the teaching process and the solutions for them such as action research.

\section{REFERENCES}

[1] Demirel, Ö. Yabancı Dil Öğretimi, MEB Yayınları, Ankara, 1999.

[2] D. Peçenek. Dilbilim eğitimi alan öğrencilerin yabancı dil öğretiminde dilbilgisi öğrenimine ve öğretimine ilişkin görüşleri. Başkent University Journal of Education, 1(1), 93-111, 2014.

[3] M. R. Memiş, M. D. Erdem. Yabancı dil öğretiminde kullanılan yöntemler, kullanım özellikleri ve eleştiriler. Turkish Studies International Periodical for the Languages, Literature and History of Turkish or Turkic. 8/9, 297-318, 2013.

[4] D. Peçenek. Yabancı dil öğretiminde dilbilgisi. Dil Dergisi, 141, 67-84, 2008.

[5] G. E. Tompkins. Language Arts: Content and Teaching Strategies. (4th Edition). Prentice-Hall. Inc., New Jersey, 1998.

[6] N. N. Şaf. Yabancı dil öğretiminde üç boyutlu dilbilgisi öğretimi. Unpublished Master's Thesis, Ankara University, Institute of Social Sciences, Ankara, 2010. 
[7] J.C. Richards, T. S. Rodgers. Approaches and Methods in Language Teaching, Cambridge University Press, New York, 2001.

[8] F. Güneş. Dil öğretim yaklaşımları ve Türkçe öğretimindeki uygulamalar. Mustafa Kemal Üniversitesi Sosyal Bilimler Enstitüsü Dergisi, 8 (15), 123-148, 2011.

[9] A. Cem. Dil bilgisi öğretiminde biçim-anlam-kullanım üçlüsü: ders malzemesi hazırlama ve uygulama önerisi. Dil Dergisi, 128, 6-11, 2000.

[10] H., Sebüktekin. Yükseköğretim Kurumlarımızda Yabancı Dil İzlenceleri, Boğaziçi Üniversitesi Yayınları, İstanbul, 1981.

[11] M. N. Gömleksiz. Yabancı dil öğretiminde kullanılan yöntemler ve yöntem sorunu. Frrat Üniversitesi Sosyal Bilimler Dergisi, 253-264, 1999.

[12] S. Maden, A. İşcan. Yabancı dil olarak Türkçe öğretimi amaç ve sorunlar (Hindistan örneği). Karadeniz Sosyal Bilimler Dergisi, 3(5), 23-38, 2011.

[13] Z. C. Karababa. Yabancı dil olarak Türkçenin öğretimi ve karşılaşılan sorunlar, Ankara Üniversitesi Eğitim Bilimleri Fakültesi Dergisi, 42(2), 265-277, 2009.

[14] M. Durmuş. Türkçenin yabancılara öğretimi: sorunlar, çözüm önerileri ve yabancılara türkçe öğretiminin geleceğiyle ilgili görüşler. Adıyaman Üniversitesi Sosyal Bilimler Enstitüsü Dergisi Türkçenin Eğitimi Öğretimi Özel Sayıs1, 6 (11), 207-228, 2013.

[15] N. Biçer, İ. Çoban, S. Bakır. Türkçe öğrenen yabancı öğrencilerin karşılaştığı sorunlar: Atatürk üniversitesi örneği. Uluslararası Sosyal Araştırmalar Dergisi, 7 (29), 125-135, 2014.

[16] E. Barın. Yabancılara Türkçenin öğretimi metodu. Dil Dergisi, 17, 54, 1994.

[17] M. D. Erdem, M. Gün, P. Sever. Türkçenin yabancı dil olarak öğretiminde yöntem seçimi ve alternatif yöntemler. Turkish Studies International Periodical for the Languages, Literature and History of Turkish or Turkic, 10/11, 549-566, 2015.

[18] A. Yıldırım, H. Şimşek. Sosyal Bilimlerde Nitel Araştırma Yöntemleri (5. Baskı). Seçkin Yayıncılık, Ankara, 2005.

[19] D. Hymes. On Communicative Competence. In Pride and Holmes, 269-93, 1972.

[20] C. Kavcar. Türkçe eğitimi ve sorunlar. Dil Dergisi, 65, 5- 18, 1998.

[21] F. Bölükbaş, F. Keskin. Yabancı dil olarak Türkçe ögretiminde metinlerin kültür aktarımındaki işlevi. Turkish Studies-International Periodical for the Languages, Literature and History of Turkish or Turkic, 5(4), 221-235, 2010 .

[22] Ö. Demircan. Yabanc1 Dil Öğretim Yöntemleri, Der Yayınları, İstanbul, 2013.

[23] Ü. Yıldız, Y. Tepeli. Yabancılara Türkçe öğretimi bağlamında yabancı dil öğretim yöntemlerinin dil bilgisi öğretimine yansımaları: iletișimsel yöntem, dil bilgisi çeviri yöntemi ve dil bilgisi öğretimi. International Journal of Language Academy, 3(1), 265-286, 2015.

[24] D.L. Freeman. From unity to diversity: twenty five years of language teaching methodology. English Teaching Forum, 20 (4). 2-10, 1987.

[25] O. Er, N. Biçer, K. Ç. Bozkırlı. Yabancılara Türkçe ögretiminde karşılaşılan sorunların ilgili alan yazını işı̆̆ı̆ı da değerlendirilmesi. Uluslararası Türkçe Edebiyat Kültür Eğitim Dergisi, 1(2), 51-69, 2012.

[26] Z. C. Karababa, S. Ü. Taşkın. Yabancı dil olarak Türkçe öğretiminde kullanılan ders kitaplarının öğretmen görüşleri çerçevesinde değerlendirilmesi. Dil Dergisi, 157, 65-80, 2012.

[27] M. H. Benhür. Türkçenin yabancılara öğretiminde tartışılmayan ana kavramlar. Unpublished Phd Thesis, Gazi University, Institute of Education Sciences, Ankara, 2002.

[28] A. Sezer, F. Oğuzkan, E. Özdemir, B. Göğüş. Türk Dili ve Edebiyatı Öğretimi (Ed. Bekir Özer). Anadolu Üniversitesi Açıköğretim Fakültesi Yayınları, Eskişehir, 1991.

[29] T. Banguoğlu. Türkçenin Grameri. Türk Dil Kurumu Yayınları, Ankara, 1990.

[30] E. Boylu, Ö. Çangal. Yabancı dil olarak Türkçe öğrenen bosna-hersekli öğrencilerin konuşma kaygılarının çeşitli değişkenler açısından incelenmesi. Uluslararası Türkçe Edebiyat Kültür Eğitim Dergisi, 4 (1), 349-368, 2015.

[31] G.P. Ladousse. Speaking personally: quizzes and questionnaires for fluency practice. Klett Ernst/Schulbuch, 2002 .

[32] E. Boylu, Ö. Çangal. Yabancılara Türkçe öğretiminde dil ihtiyaç analizi: betimsel bir durum çalışması. International Journal of Language Academy, 2(4), 127-151, 2014.

[33] R. Özyürek. Türk devlet ve topluluklarından Türkiye üniversitelerine gelen türk soylu yabancı uyruklu öğrencilerin Türkçe öğrenimlerinde karşılaştıkları sorunlar. Turkish Studies International Periodical for the Languages, Literature and History of Turkish or Turkic, 4 (3), 1819-1862, 2009.

[34] M. E. Sallabaş. Türkçeyi yabancı dil olarak öğrenenlerin konuşma kaygılarının değerlendirilmesi. Turkish Studies International Periodical for the Languages, Literature and History of Turkish or Turkic, 7(3), 2199-2218, 2012.

[35] D., Larsen-Freeman. Teaching Language: From Grammar to Grammaring. Heinle\& Heinle, Canada, 2003.

[36] M. Hengirmen. Yabancı dil öğretim yöntemleri ve TÖMER yöntemi. Kültür Matbaacılık, Ankara, 1993.

[37] H. D. Brown. Teaching by Principles: An Interactive Approach to Language Pedagogy. Longman/ Pearson Education, White Plains: New York, 2001.

[38] H. Nassaji, S. Fotos. Teaching grammar in second language classrooms. Integrating form-focused instruction in communicative context. Routledge, London, 2011. 